\title{
Effects of the $\mathbb{d}_{2}$ dw arfing gene in pearl millet*
}

\author{
F. R. Bidinger and D.S. Raju

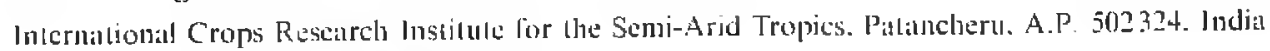

Received Seplember 21, 1989: Aceepled Decembor 12. 1989

Communicated by G.S. Khush

Summary. Dwarf varieties halve had virtually no impact on the production of pearl millet, in contrast to the case of wheilt, rice. and sorghum. This research compared tall and dwarr near-isogenic $F_{1}$ hybrids to attempt to determine if there were deleterious effects of the $d_{2}$ dwarfing gene that might account for the lack of release/cultivaltion of dwar' pearl millet cultivars. Dwarl isohybrids on average yielded Jess than the lalls. because of a smaller average seed size combined with al similar grailn number per unit area. There was, however, a larger contribution of background genetic variation (pollinator. male-sterile, and interaction ef(ects) to hybrid variation for nearly all characters measured. including seed size. than there was of the dwarling gene. Selection of dwarl parents capable of producing hybrids with equal seed size and yield to that of tall parents should not be diflicult.

Key words: Pearl milfet - Dwarling gene - Parental effects - Near-isogenic hybrids

\section{Introduction}

During the last 20 years. dwarfing genes have had at large impact on the breeding of wheal and rice worldwide, and of sorghum in temperate zones. In all three cercals. dwarling genes have provicled protection from lodging, and have allowed the productive use of high levels of inputs. In the case of sorghum. dwarf loybrids have made mechanical harvesting possible. In wheat, in addition to these benefits. the Rh serics of dwarling genes has benelicial pleiotropic effects on yicld potential through increases in grain numbers per spike or in tiller number (Gale and Youssefian 1985).

\footnotetext{
* Journal article no. 1469 of the International Crops Research Institule for the Senji-Arid Tropics. Piltinchert. A P. 502324. India
}

Dwarling genes have been known in pearl millet [ $P$ enmisctum glancum (L.) R. Br.] for more than 20 years (Burton and Fortson 1966) and have been used, at least cxperimentally. by plint breeders for almost as long (Bakshi et al. 1966; Chantereau and Etasse 1976: Lambert 1983: Thakare and Murty 1972). To the authors" knowledge, however. dwarf varieties or hybrids have hitd virtually no impact on the production of the crop. in contrast to the history of dwarf varieties of wheal. rice, or sorghum.

Reports from West Africal of comparisons of dwarf and standard height varicties indicated yield advantages of $5 \%-15 \%$ in the dwarls (Lambert 1983). However. these varielies had problems of greater disease susceptibility and poor grain filling (Niangedo and Ozlendeba 1987), and have never been grown by farmers. Comparisons of dwarf and till versions of a sel of seven composites of boh Indian and Alrican origin indicated no overall yield advantage to the dwares (K.N. Rail. personal communication). In India. where more than 40 varicties and hybrids have been released since the 1960s, only a single dwarl' cultivar has been released. which was never widely grown.

This research was undertaken to more critically examine the effects of the $d_{2}$ dwaring gene (Burton and Fortson 1966) on growth and yiekd in it set of neilr-isogenic tall/dwarf F, hybrids of pearl millet. The specific purpose was to delermine if there is any evidence of adverse effects associated with the $d_{2}$ gene. which might be responsible for the lack of impact of clwarf cultivars on pearl millet production.

\section{Materials and methods}

Hybrids

The near-isogenic lall/dware hybrids were made by crossıng lour pairs of near-isogenic tall $\left(D_{2} D_{2}\right) / d w a r f\left(d_{2} d_{2}\right)$ inhred lines on 
Table 1. Meanl. ranges, and standard ejror for the 32 hybrids. and the mean eflects of the various components of the hybrids for growth. yicld. and yield components

\begin{tabular}{|c|c|c|c|c|c|c|c|}
\hline & $\begin{array}{l}\text { Stem bl. } \\
\text { (cin) }\end{array}$ & $\begin{array}{l}\text { Biominss } \\
\left(\mathrm{l} \mathrm{m}^{-21}\right.\end{array}$ & $\begin{array}{l}H+11 \\
(" 0)\end{array}$ & $\begin{array}{l}\text { Grain yicld } \\
\left.\text { (g } \mathrm{m}^{-3}\right)\end{array}$ & $\begin{array}{l}\text { Grain no. } \\
\left(10^{-2} \mathrm{~m}^{-2}\right)\end{array}$ & $\begin{array}{l}\text { Grain miss } \\
\text { (meg gralin }{ }^{-1} \text { ) }\end{array}$ & $\begin{array}{l}\text { Flowering } \\
\text { (days) }\end{array}$ \\
\hline \multicolumn{8}{|l|}{ Hybrid } \\
\hline Meinl & 150 & 785 & 37.7 & 289 & 37.6 & 7.95 & 44.7 \\
\hline Range & $104-196$ & $613-985$ & $32.1-42.1$ & $236-337$ & $27.2-49.6$ & $5.000-10.68$ & $39.9-50.8$ \\
\hline $\mathrm{SE}^{4}$ & 0.79 & 2.7 & 0.53 & 1.8 & 0.65 & $0.2+5$ & 0.26 \\
\hline$F$-ratlio & it & $* * *$ & $* * *$ & $* * *$ & *末冰 & $* * *$ & $* * *$ \\
\hline \multicolumn{8}{|l|}{ I-loight class } \\
\hline Tilll & 177 & $8+6$ & 36.8 & 303 & 37.1 & 8.40 & +4.9 \\
\hline Dwarl & 122 & 724 & 38.7 & 276 & 38.0 & 7.51 & $4+.5$ \\
\hline$f$-ralio & $* * * *$ & $* * *$ & $* * *$ & $* * *$ & NS & $* * *$ & $* * * *$ \\
\hline \multicolumn{8}{|l|}{$\wedge$ lines } \\
\hline $8+3 \mathrm{~A}$ & $1+1$ & $7+1$ & 38.4 & 278 & 32.9 & 8.74 & 41.3 \\
\hline $81 \mathrm{~A}$ & 159 & - $85 ?$ & 35.6 & 297 & -16.1 & 6.50 & 49.0 \\
\hline $8.33 \mathrm{~A}$ & 148 & 789 & 37.3 & 289 & 37.2 & 7.81 & +5.1 \\
\hline $8+2 \mathrm{~A}$ & 152 & 760 & 39.7 & 293 & 34.4 & 8.73 & +3.5 \\
\hline F-rilio & $* * *$ & *末* & $* * *$ & ** & sil 4 & $H k$ & * क* \\
\hline \multicolumn{8}{|l|}{$R$ lines (pairs) } \\
\hline ECIL-33-6-3-3/2 & 160 & 826 & 39.3 & 317 & 36.0 & 9.01 & 44.7 \\
\hline ECIL-159-4-4-7/8 & 137 & 732 & 37.5 & 271 & 38.6 & 7.11 & 44.4 \\
\hline MCIL-31-5-2-2.12 & 145 & 743 & 38.3 & 279 & +2.4 & 6.71 & +4.1 \\
\hline$N C I L-1+3-4-5-3 / 6$ & 158 & 838 & 35.9 & 291 & 33.4 & 8.97 & $\$ 5.7$ \\
\hline$F$-rallio & $* * *$ & $* * *$ & $* * *$ & 柰* & $k=k * k$ & $* * *$ & $* * *$ \\
\hline CV"is & 5 & 11 & 9 & 13 & 14 & 9 & 2 \\
\hline
\end{tabular}

: SE ol individual hybrid values

**,*** Significaml al the 0.01 and 0.001 levels ol probability, respeclively. by $F$-lest

four dwarf $\left(d_{2} d_{2}\right)$ male-slerile lines (Table 1). The near isogenic inbred lines were derived from progenies, segregating for the $d_{2}$ genc. [rom a backcrossing program to produce dwarl versions of standard height composiles. Tall plants in progenies segregating for dwarliness were selled each generation from the $\mathrm{BC}_{3} \mathrm{~F}_{3}$ to $\mathrm{BC}_{3} \mathrm{~F}_{7}$. Phenotypically similar lall and dwarl plants were selected in segregating progenies in the $F_{H}$ generation. and were advineed by an akditional generation of selfing. Crossing four lall/dwarl pairs onto Tour dwar phenolypically diverse malesterile lines produced 16 pairs of tall $\left(D_{2} d l_{2}\right)$ and dwarf $\left(d l_{2}\left(l_{3}\right)\right.$ hybrids. Hybrids were used in prelerence to the original inbred lines (which have significant inbreeding depression) as the dwarling gene. if used commercially. would most likely be in $F_{\text {, }}$ liybrid form. The consequences of the lalls being helerozygous rather that homozygous alt the $D_{2} d_{2}$ locus are not known. but compasisons of homozygous and heterozygous tall bybrids in sorghum indicaled no overdoninance alleces (Campbell al. [975).

\section{Erilitation}

The 16 pairs of hybrids were grown in replicaled liseld trials al the IC'R ISAT Cenler during the rainy seasons of 1985.1986 . and 1987 in a raudomized block design. withoul blocking by hejght. Individual plots were four (1986-1987) or six (1985) rows of $0.75 \times 4.0 \mathrm{~m}$. All observaltions were tilken on a 3.0-n Iength of the center two rows (1986-1987) or the center four rows (1985). Plols were well lerlijized $\left(85-100 \mathrm{~kg} \mathrm{~N}\right.$ ha ${ }^{-1}$ plus $20-25 \mathrm{~kg}$ [ $h_{a}{ }^{-1}$ ). and were overplanted and limned to a uniform plant stand of I? plants m ${ }^{2}$. Weed control was by cultivation and a single-hand weeding; no significint diseilse or pest incidence occured in any year.

Dati were recorded on flowering. plant leigh, biomalss. grain yield. and yield components in all 3 years. Analysis of all data was done according to the [jeld design, considering replicale as contained within year. and partitioning the sums of sc]uitres for hybrid (3) (/) into effects of heighn (I $d / f$ ). male-sterile. and pollinator pair $(3 \mathrm{~d} / \mathrm{each})$. and the varjous interactions umong these effects. The elfects of the $d_{2}$ gene on the meisured variables were assessied by comparing the proportion of the sums of squares for hybrids thal was attributable to height. als opposed to that attributable to parental alfects and interactions of height and parental effects.

\section{Resulis and discussion}

\section{Differences in rall and duranf isohyrids}

Individual trial mean yields were 2.63 tons hat $^{-1}$ in 1985 , 3.42 tons ba ${ }^{-1}$ in 1986 , and 2.62 tons ha $^{-1}$ in 1987, which are normal values for non-irrigaled experiment station yields. Individual hybrids differed significantly for all cliaracters mealsured (Table 1).

The elfects of the alleles at the $D_{2} / d_{2}$ locus (henceforth called height class) were significant for all váriables measured except grain number $\mathrm{m}^{-1}$ (Table 1). Some of the differences between the lalls and dwarls were expected (lesser straw lenglh and total biomass, and a 
higher harvest index (HI) in the dwarfs (Table I) from results of similar comparisons in wheat (review by Gale and Youssefian 1985). barley (Ali ef al. 1978), and sorghum (Windscheffel et al. 1973). Similarly, the smaller individual grailn mass found in the dwarf millet hybrids hals been widely reported in dwarf lines of other crops (e.g.. Gale and Yousselian 1985: Ali ef al. 1978: Campbell et al. 1975).

Grain numbers per unit area were not different in the lall and dwarf hybrids (Table $J$ ) and. as al consequence. grain yields were significantly less in the dwarfs than in the talls. following differences in grain mass. Millet appears to differ from wheal (Gale and Youssefian 1985) and possibly barley (Ali et al. 1978), in which increases in grain number in dwarf lines, achieved either by increases in griin number per spike (mainly in winter wheal) or in spike number (spring wheal and barley). offset the decrealse in individual grain mass. Sorghum. on the other hand. appears to be more similar to millet. as most reports indicate a smaller grain size without a compensilting increase in grain number in dwarf isolines/hybrids (Camphell el al. 1975: Cassady 1965: Schertz. 1973).

Why there is a much more consistent increase in grain numbers associaled with the $R / h_{1}$ or $R / h_{2}$ alleles in whert (versus the tall $r$ allele) than there is in dwarf sorghum or millet is not clear lrom the literat ure. Increases in gratin number per spike in winter wheat mily be due to its having an indeterminate number of noret primordia per spikelet. which mily make wheal much more responsive, at least under some environmental conditions, to a reduction in competition between spike and stem during the later part of stem elongation. when the florets are developing and linal floret number is being determined (Brooking and Kirby 1981: Bush and Evans 1988). Crops with a predetermined floret number per spikelel, such as barlcy, sorghum. and millel. may be less likcly to respond in this fastrion to a change in partitioning between slem and spike/punicle.

The differences in individual grain mass between the tall and dwarf isolyybrids were examined in more delail by ploting individual grain mass for both iall and dwarr hybricls atgitinst grain number per unit area. as the latter is generally the major determinant of individual grain malss in most cereals. This was clearly the calse in these hybrids. as grain number aceounted for $71 \%$ of the variation in individual grain mass (Fig. J). It is clear (rom this plot, however, that the relationship of the two variables differed in the tall and dwarl hybrids for grain numbers grealter than aboul $34,000 \mathrm{~m}^{-2}$. Most but not all) of the dwarfs had a grain mass of the order of I $\mathrm{mg}$ per grain $(12 \%-20 \%)$ less than that of the tills over the range of $34.000-50.000$ grains $\mathrm{m}^{-2}$. Thus. the yield disadvantages of the dwarfs were specifically associaled wills a poorer ability lo fill grains in genetic backgrounds that produce higher grain numbers.

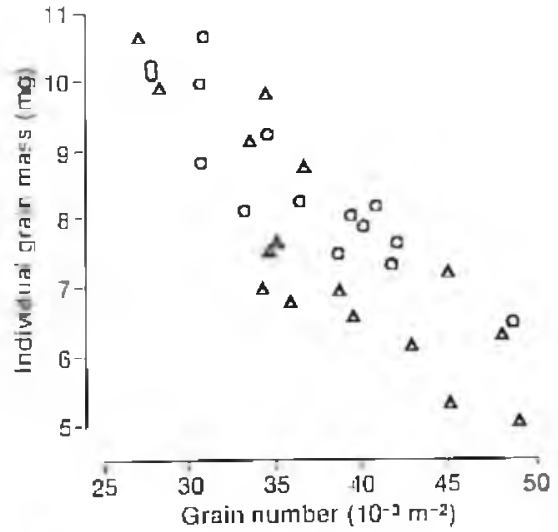

Fig. 1. Relationship of individuin grain mass and grain number per unir alrea for the tall (o: and dwarl (a) isogenje hybrids. Dilti are means of 3 years

\section{Relative contrihusom of the thathing gene}

In addition to the effects of the dwarf habit, there were also significant elfects of both male-sterile and polinator for all variables measured, as assessed by the mean eflects of parents over the hybrids made with them (Tuble 1). Hybrids made with 843 A. c.g. . lowered earlier, produced less biomass. and were lower yie]ding than hybrids on the other three malc steriles. Similarly, hybrids made with ECIL-33-6-2-3/2 and NCIL-1 43-4-5-3/6 were taller. produced more biomass, had larger grains, and ontyialded those made with the other two pollinator pairs.

Since the dwarf habit represents an alternative that a plant breeder maly or mily not cmploy, it seemed most logical to compare its effects directly to those of his other alternative - the choice of parents. This was done by partitioning the sums of sculares (SS) for hybrid in the ANOVA among the component effects (Table 2). Height cliss, as expected. alccounted for the majority of variattion in stem length $(83 \%)$ and biomass $(43 \%)$. The offect of height class on harvest index. however. was ball or less than the effects of both parental groups. In addition, the interaction of height class and pollinator accounted for a grealter proportion of the variation in HI than dij height class alone. Thus, attempts to manipulate HI (for example) would be likely to be more successful through choice of parcntal lines than by the use of the $d_{2} \mathrm{dwarfing}$ gene.

Variation in hybrid grain yield and yield components was more strongly influenced by variation among parental lines than it wils by differences in height cliss (Table 2). Grain number differences in the hybrids were primarily a result of male-sterile line differences $(64 \%$ of the SS). Pollinator differences were primarily responsible lor differences in grain mass ( $47 \%$ of SS) and grain yield (35\% of SS). Interactions between heiglat class and parental line were generally smaller than the individual effects of each. with the exception of a relatively large effect of pollinator $\times$ height class on grain yield $(17 \%$ of 
Table 2. Percentages of the sums ol squares for hybrids accounted for by the various component sources of variance within hybrid

\begin{tabular}{|c|c|c|c|c|c|c|c|c|}
\hline & $d i$ & Slem bا. & Biomass & HI & Grain yield & Grain no. & Grain miss & Flowering \\
\hline Hybrid & 31 & 1010 & 100 & 100 & 100 & 100 & 100 & 100 \\
\hline Heighu class & 1 & $83 * * *$ & 43*水米 & $12^{* * * k * k}$ & $20 * * * *$ & 1 & $9 \div * *$ & $1^{* * * *}$ \\
\hline A line & 3 & $5 * * *$ & $20^{* * *}$ & $33 * * *$ & $6^{* * *}$ & $64 * * *$ & $36^{* * *}$ & 88 **** \\
\hline $\mathrm{R}$ line & 3 & 10) il:** & 26 *** & 23 * *:t: & 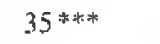 & 27 ***as & $47^{* \cdots * 2 * 3}$ & f 氺 \\
\hline$A \times R$ lines & 9) & $<1^{* * * * *}$ & 4 & $8 *$ & 11 **** & 2 & $5 * * *$ & 3 *⿻丷木 \\
\hline $1 \| \times \Lambda$ line & 3 & |*** & I & $6 * *$ & $6^{m * * *}$ & $<1$ & $1 * *$ & $<1^{*}$ \\
\hline $\mathrm{H}: \times \mathrm{R}$ line & 3 & $<\left.\right|^{*}: *=$ & 3 & 15 皮束米 & $17 * *$ & $3 * * 2$ & 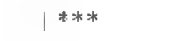 & $4^{* * *}$ \\
\hline II $\times A \times R$ linus & 9 & $<1:$ & 2 & 3 & 4 & 2 & $1 * *$ & $1: * *$ \\
\hline
\end{tabular}

*, ***,*** Significant at the $0.05,(0.01$. and (0.001 levels of probability. respeclively, by F-test

the SS for hybrid). Therefore. despite lower mean grain mass and grain yicld in the dwarf isohybrids, the partition of variance makes it clear that. by selection of parental lines. it is possible to produce $d_{2}$ dwarl hybrids with yields equal to those of the tall hybrids. In fact the highlest yielding hybrid in the trial was a dwarl 842A $\times$ ECIL-33-6-2-2 - with a grain mass of more than $9 \mathrm{mg}$ grain $^{-1}$. While the relative eflects of maje-sterile or pollinator maly be specilic to the lines used. the general elfects of genetic background on expression of the $d_{2}$ gene are clearly large.

Large effecls of genetic background on the performance of dwarf isolines have been widely reported in other crops (e.g.. Ali el all. 1978: Cassaldy 1965: McClung el al. 1986 ). and specifically studied in wheat by Busl and Evans ( 1988 ). These authors found large inteructions of R/h genes and not only specilic genelic background. but also R/f genes and environmental conditions. which were expressed as differences in crop growth, stem length. ear number, grain number per ear, and grain yield. The results of this study clearly supporl Bush and Evans' (1988) findings: in spite of a mean depressive effect of the dwarfing gene on individual grain mass and grain yield. the effects of the specilic parental combination. particularly the interaction of dwarfing gene and pollinator in the case of grain yield. clearly outweigh the effects of the dwarling gene on the hybrid phenotype. This is clearly illustrated in Fig. I, in which two of the dwarl hybrids produced both a high grain number per unit area and a gratin size equal to that of the best tall hybrids (for their grain number). Thus. breeding programs on dwar[ pealr] millet should be successful if they are designod to take advantage of positive interactions between the dwarl habit and specific genetic background which, these dalta indicate. are large and useful.

Hcknomedgements. The authors wish to express their appreaiation to Dr. K. N. Rais of ICR ISAT for furnishing the tall/dwarl' isogenic lines used as pollinalors in this study.

\section{References}

Ali MA. Okiror SA, Bradshaw DC (1978) Perlormance ol semidwarf barley. Crop Sci 18:418-422

Balishi JS. Rachie KO. Siugls A (1966) Development of dwarl strains of pearl millel and atn assessment of lieir yield polenial. Curr Sci 35:355-356

Brooking ]R. Kirby EJM (1981) Interrelationships between slem and ear development in winter wheilt: the effects of a Norin 10 dwarling gene. Gai/R/h2. J Agric Sci 97:373-381

Burton GW. Fortson JC (1966) fntheritance and utidization of live dwarls in pearl malle ( $P$ (mmisctwm trphoirles) breeding. Crop Sci 6:69-72

Bush MG. Evans LT (1988) Growth and development in 1all and dwarl isogenic limes of spring wheith. Fjeld Crops Res 18:243-270)

Cimplell LG. Cassady AJ. Crook WJ ( 1975 ) Effects of a single heigh gene (Dil $)$ of sorghum on certain agronomic cluaracters. Crop Sci 15:595-597

Cassady AJ (1965) Ellects ol" as single height $(D W)$ gene of sorghtum on graitin yielal, gerain yicld components, and lest weight. Crop Sci 5:385-388

Chantereau J. Etasse C (1976) Creation des populations naines de mil pennisetum (Pemixenum typhoides Slapl) au Niger. Agron Trop 31:254-257

Gale MD. Yousselian S (1985) Dwalling genes in wheal. In: Russel GE (ed) Progress in plant breeding. Bullerworlhs. London. pp I-35

Lambert C (1983) L'IRAT et l'amelioriation du mil, presenalIion des lavaux. Agron Trop 38:78-88

McClung A. Cantrell RG. Quick JS. Gregory RS (1986) In[luence of the $R / h_{1}$ semi-dwarl gene on yicld, yield components, and grain protein in Jurum wheal. Crop Sci 26:1095-1099

Niangado 0 . Ouendeba $B$ (1987) A melioralion varietale du mil en Alrigue de l'Ouest. In: Proc Int Pearl Millet Workshop. April $7-11,1986,1$ CRISAT Center. Patilncheru. India. pp $83-9+4$

Schertz ḱl: (1973) Single height gene ellects in hybrids ol doubled haplod Sorghwm hicolor (L). Crop Sci 33:421-+23

Thakare RB. Murly BR (1972) Incorporation of Jwarling loci in populations of pearl millet. Indian J Genel Plant Breed 32: $445-450$

Windselve[fel JA. Vanderlip RL. Citssady AJ ([973) Performance of 2-dwarl and 3-dwarl grain sorghum loybrids harvested al various moisture conlents. Crop Sci $13: 215-219$ 